Volume 10 Number 4, October-December 2016: pp. 605-820.

Copyright (c) 2015-2016 FIAT JUSTISIA. Faculty of Law, Lampung University, Bandarlampung, Lampung, Indonesia. ISSN: 1978-5186 | e-ISSN: 2477-6238.

Open Access: http://jurnal.fh.unila.ac.id/index.php/fiat

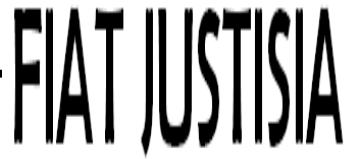

Fiat Justisia is licensed under a Creative Commons Attribution 4.0 International License, which permits unrestricted use, distribution, and reproduction in any medium, provided the original work is properly cited.

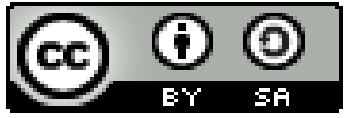

\title{
PERLINDUNGAN HAK PATEN (Studi Komparatif Lingkup Perlindungan di Berbagai Negara)
}

\author{
PATENT PROTECTION \\ (Comparative Study on Scope Protection in Many Countries)
}

\author{
Sutarman Yodo \\ Fakultas Hukum, Universitas Tadulako \\ Email: sutarman.yodo@gmail.com
}

\begin{abstract}
The differences of the legal system that patent scope protection in various countries, not only importing for new investment but determine the process of transfers of the technology of a state. Widespread protection cause transfers of technology become not easy eventhought less protection cause patent owner quit being lost. Both difference intention results in the need of comparative study on protection scope of the patent in countries. There are two problems should be explored, first what is the difference and similarity scope patent protection in the state's regulation and the second how legal system influenced to the differ occurrence? These problems used research methods that are statute approach and comparative approach, case approach, and conceptual approach. Result research found patent protection in Europe countries, United State, Japan, and Indonesia had similarity in protection requirement regulated such novelty, inventive step, and industrial applied. However, United State protection base on first to invent meanwhile other state based on first to file. Then scope of patent protection there has Germany applied the widest protection, then United State, and Japan, then Netherland. Mean England as the limited protection country. The difference patent protection is influenced by the legal system such common law that more referred to the precedent than civil law system with its codification. Germany is the only one country applied rigid codification on patent protection. Means, Indonesia formulated the of patent protection that is still limited related to the limited cases resolved in court.
\end{abstract}

Keywords: Patent Right, Scope Protection, Comparative Law. 


\begin{abstract}
Abstrak
Perbedaan sistem hukum perlindungan lingkup paten di berbagai negara, tidak hanya mengimpor investasi baru namun juga menentukan proses transfer teknologi suatu negara. Perlindungan yang meluas menyebabkan transfer teknologi menjadi tidak mudah walaupun kurangnya perlindungan karena pemilik paten mengalami kerugian. Kedua perbedaan niat tersebut menghasilkan perlunya studi komparatif tentang cakupan perlindungan paten di negara-negara. Ada dua masalah yang harus dijajaki, pertama apa perbedaan dan kesamaan cakupan perlindungan paten dalam peraturan negara dan yang kedua bagaimana sistem hukum mempengaruhi kejadian yang berbeda? Masalah ini akan menggunakan metode penelitian pendekatan statuta menyeluruh dan pendekatan komparatif, pendekatan kasus, dan pendekatan konseptual. Hasil penelitian menemukan perlindungan paten di negara-negara Eropa, Amerika Serikat, Jepang, dan Indonesia memiliki kesamaan dalam persyaratan proteksi yang mengatur hal baru, langkah inventif, dan penerapan industri. Namun, perlindungan di Amerika Serikat pada awalnya untuk menciptakan sementara basis negara lain berdasarkan berkas pertama. Kemudian ruang lingkup proteksi paten di sana telah ada Jerman menerapkan proteksi terluas, kemudian Amerika Serikat, dan Jepang, lalu Belanda. Berarti Inggris sebagai negara perlindungan terbatas. Perbedaan proteksi paten dipengaruhi oleh sistem hukum common law yang lebih mengacu pada precedent daripada civil law dengan kodifikasinya. Jerman adalah satu-satunya negara yang menerapkan kodifikasi yang kaku terhadap perlindungan paten. Berarti, Indonesia merumuskan cakupan proteksi paten yang masih terbatas yang terkait dengan terbatasnya kasus yang diselesaikan di pengadilan.
\end{abstract}

\title{
Kata kunci: Hak Paten, Perlindungan Ruang Lingkup, Hukum Komparatif
}

\section{A. Pendahuluan}

Perkembangan teknologi suatu negara, tidak lepas dari aspek perlindungan hak paten yang berlaku pada negara tersebut. Negara Jepang sebagai contoh, adalah negara yang dikenal paling maju teknologinya. Semula negara ini banyak mencontoh teknologi negara-negara Eropa dan Amerika, namun dalam perkembangan yang kita ketahui akhir-akhir ini justru Jepang-lah yang menjadi kiblat dari negara-negara lain termasuk Eropa dan Amerika.

Dalam perlindungan hak paten, apabila lingkup perlindungan yang diberikan terlalu luas kepada pemegang hak paten, maka sistem perlindungan hukum tersebut berdampak pada proteksi hak paten yang dipegang oleh seseorang menjadi sangat kuat, namun proses alih teknologi pada negara tersebut tidak mudah terjadi, sebab modifikasi yang tidak 
substansial pun dari pihak lain masih bisa dinilai sebagai pelanggaran hak paten. Sebaliknya apabila perlindungan yang diberikan kepada pemegang hak paten terlalu sempit, maka pemegang hak paten mudah dirugikan karena adanya modifikasi yang substansial pun masih bisa dinilai bukan sebagai pelanggaran hak paten, namun berpengaruh positif terhadap perkembangan tekonologi negara tersebut.

Bukan suatu yang tidak mungkin terjadi, dalam suatu negara terdapat lebih dari satu pemohon paten atas penemuan-penemuan yang mempunyai kemiripan satu dan lainnya. Dalam hukum paten dapat terjadi pemohon pertama yang akan diberikan paten oleh suatu negara, tetapi belum tentu bagi negara lain yang menggunakan aturan atau prinsip "first-to-invent". Akan tetapi baik first-to-file maupun first-to-invent, keduanya menutup kemungkinan pihak lainnya yang memiliki kemiripan dengan penemuan yang telah dipatenkan diterima penemuannya sebagai hak paten. Atas dasar kedua prinsip tersebut, lingkup perlindungan paten dari masing-masing negara tersebut menjadi penting untuk diketahui. Oleh karena hanya dari aspek lingkup perlindungan yang dimaksud, suatu penemuan baru bisa diberikan hak paten, sepanjang hasil penemuan tersebut tidak memiliki kesamaan dengan yang telah didaftarkan sebelumnya menurut prinsip firstto-file atau first-to-invent.

Berbagai negara dalam menentukan luas perlindungan paten, meletakan syarat pada klaimnya dengan sistem yang berbeda. Perlakuan yang berbeda pada masing-masing negara tersebut, menjadi lebih menarik apabila dihubungkan dengan pengelompokkan sistem hukum civil law dan common law yang pernah kita dikenal sebelumnya. Dalam sejarah sistem common law yang menolak kodifikasi yang berlaku dalam system civil law, akan mempersulit upaya mendapatkan penjelasan secara detail tentang konsep klaim yang dimaksud dalam hukum paten.

Pada negara-negara common law seperti Amerika Serikat dan Inggris, rujukannya tertuju pada doktrin "preseden" (precedent). Akan tetapi hal tersebut belum menyelesaikan masalah, karena dalam pelaksanaannya antar negara common law tidak melihat sama preseden untuk suatu kasus, misalnya preseden yang berlaku di Inggris dalam melihat luas perlindungan hak paten belum tentu sama dengan preseden yang berlaku di Amerika Serikat. Demikian pula dalam menafsirkan klaim yang menentukan luas perlindungan hak paten. Suatu negara terkadang penafsirkan intisari dari klaim yang diajukan hingga berdampak pada bentuk perlindungan yang demikian luas kepada pemegang hak paten tetapi menyulitkan proses alih teknologi. Sebaliknya dengan negara tertentu menafsirkannya dari kata-kata dalam klaim yang berakibat perlindungan hak paten kepada pemegang menjadi sempit, namun memudahkan proses alih teknologi kepada pihak yang melakukan modifikasi. 
Uraian di atas menempatkan lingkup perlindungan hak paten sebagai issue pokok yang sangat penting untuk dikaji. Atas dasar issue tersebut, permasalahan yang perlu dikaji dirumuskan sebagai berikut:

1. Apa saja persamaan dan perbedaan lingkup perlindungan paten yang berlaku di berbagai negara?

2. Bagaimana pengaruh sistem hukum terhadap perbedaan lingkup perlindungan paten di negara-negara penganut sistem civil law dan common law?

Upaya menjawab permasalahan tersebut, digunakan metode penelitian hukum normatif berdasarkan metode statute approach dan comparative approach, di samping case approach dan conceptual approach.

Melalui metode penelitian hukum normatif dengan berbagai pendekatan yang dimaksud, diharapkan lingkup perlindungan hak paten yang berlaku di berbagai negara akan mudah diketahui, minimal hal ini bermanfaat dalam menghindari perang global akibat dominasi ekonomi melalui penguasaan paten. Demikian, Fred Warshoefsky ${ }^{1}$ mengatakan, saat ini perang global yang terkeji dalam upaya pendominasian ekonomi adalah mengenai hak atas kekayaan intelektual. Saat ini dan masa mendatang Indonesia akan bertikai terhadap ide, inovasi, kreasi dan penemuanpenemuan. Kancah peperangan bukan di medan perang tapi di forum Pengadilan, yang merenggut jutaan dolar melalui litigasi paten.

\section{B. Pembahasan}

\section{Perlindungan Paten Negara-Negara Eropa}

Konvensi Paten Eropa, Undang-Undang Paten Jerman, Amerika Serikat, dan Jepang, dalam makalah "Comparative Study on the Japanese, the United States and the European Patent Systems", oleh Japan Patent Office Asia-Pacific Industrial Property Center di Jepang belum lama ini (tahun 2001), bila ditelaah banyak mengungkap persamaan/perbedaan perlindungan paten negara-negara tersebut. Beberapa pasal konvensi dan undang-undang negara dimaksud, memperkaya isi tulisan ini.

Walaupun di antara negara-negara Eropa yang menandatangani Konvensi Paten Eropa dan telah menyesuaikan perundang-undangan nasionalnya, masih terdapat perbedaan penafsiran konsep tentang lingkup perlindungan paten. Seperti ketentuan dalam Pasal 69 ayat (1) Konvensi Paten Eropa menyebutkan: Theextent of the protection conferred large a European or a European patenapplication shall be determined large the

\footnotetext{
${ }^{1}$ Maulana, Insan Budi. (2000). Penerapan Paten Sejak UU Paten No. 6 Tahun 1989 Hingga UU Paten No. 13 Tahun 1997: Pengalaman Indonesia Selama Ini, dalam Kapita Selekta Hak Kekayaan Intelektual I, Pusat Studi Hukum UII Yogyakarta Bekerja Sama dengan Yayasan Klinik HAKI Jakarta, p. 4.
} 
term of claims. Nevertheless, thedescription and drawings shall be used right interpret the claims. Bagi Belanda hal ini tertuang dalam Pasal 30 ayat (2) Undang-Undang Belanda 1986, yang intinya menentukan bahwa yang dilindungi adalah isi klaim, bukan perumusan secara harfiah klaim yang disertakan dalam permohonan paten suatu penemuan.

Pembentuk undang-undang tidak bermaksud mengkaitkan luas perlindungan paten dengan urusan alih teknologi. Hal ini disebabkan setting masyarakat Belanda dengan pola perekonomian yang sudah maju dijiwai oleh semangat kapitalisme. Perlindungan yang ditujukan pada isi klaim memberikan perlindungan yang luas. Sementara Konvensi Paten Eropa ingin menghindari perlindungan paten yang ditafsirkan terlalu luas, karena akan mengganggu persaingan

Dalam praktek tampak lain sikap pengadilan Belanda. Menurut Pieroen bahwa Pengadilan tidak terikat pada Penjelasan Undang-Undang. Hakim diberi kebebasan dalam menafsirkan ketentuan undang-undang. Pendirian pengadilan Belanda itu sudah sesuai dengan maksud yang dikandung Konvensi Paten Eropa karena memberikan perlindungan yang seimbang baik terhadap pemegang paten maupun kepada pihak ketiga. Protokol Konvensi Paten Eropa memang menghendaki adanya perlindungan hukum yang seimbang antara pemegang paten dan masyarakat. ${ }^{2}$

Di Jerman pada Bagian 6 Undang-Undang Paten menetapkan bahwa jika dua orang atau lebih telah membuat penemuan secara independen satu terhadap yang lain, maka haknya akan menjadi milik orang yang pertama mengajukan permohonan kepada kantor paten. Jadi mengikuti aturan first-tofile, sebagaimana isi Pasal 60 Konvensi Paten Eropa.

Mengenai ketentuan Bagian 1 (1) Undang-Undang Paten Jerman, mengatur penemuan yang bisa dipatenkan haruslah baru, melibatkan suatu langkah inventif, dan memungkinkan untuk aplikasi industrial, juga sama dengan isi Pasal 52 ayat (1) Konvensi Paten Eropa. Menurut Bagian 3 Undang-Undang Paten Jerman, suatu penemuan harus dianggap baru jika penemuan tersebut bukan merupakan bagian dari the state of the art (sama dengan Pasal 54 ayat (1) Konvensi Paten Eropa).

Dalam Pasal 54 ayat (2) Konvensi Paten Eropa menyebutkan: The state of the art harus dianggap sebagai segala sesuatu yang dibuat tersedia untuk publik melalui deskripsi tertulis atau lisan, penggunaan, atau dengan cara lain apapun, sebelum tanggal pengajuan permohonan paten eropa. Ketentuan dalam Bagian 4 Undang-Undang Paten Jerman yang menjelaskan langkah inventif, dan Bagian 5 Undang-Undang Paten Jerman menjelaskan

\footnotetext{
${ }^{2}$ Marzuki, Peter Mahmud. (2000). Luasnya Perlindungan Paten, dalam Kapita Selekta Hak Kekayaan Intelektual I, Pusat Studi Hukum UII Yogyakarta Bekerja Sama dengan Yayasan Klinik HAKI Jakarta, p. 36.
} 
aplikasi industrial, sama dengan Pasal 56 dan 57 Konvensi Paten Eropa. Pasal 56 Konvensi Paten Eropa menyebutkan suatu penemuan akan dianggap melibatkan suatu langkah inventif jika, setelah mempertimbangkan the state of the art. Dibandingkan dengan ketentuan Pasal 57 Konvensi, maka suatu penemuan akan dianggap sebagai aplikasi industrial jika penemuan bersangkutan bisa dibuat atau digunakan dalam suatu jenis industri, termasuk pertanian.

Berlakunya ketentuan perundang-undangan Jerman yang menyesuaikan Konvensi Paten Eropa tersebut, merupakan upaya untuk menyisihkan ketentuan yang memberikan perlindungan begitu besar kepada penemuan. Melalui ketentuan itu, luas perlindungan paten dipersempit. Dalam Pasal 14 Patengesetz 1981, disebutkan luasnya perlindungan paten ditentukan oleh "isi materiil klaim". Perlindungan di luar kata-kata klaim hanya dapat diperluas untuk: ${ }^{3}$

a. Perwujudan penemuan yang ekuivalen,

b. Perwujudan penemuan yang belum selesai, dan

c. Perwujudan-perwujudan penemuan yang berbeda dari klaim utama yang di dalamnya tidak terdapat ciri-ciri yang non-esensial.

Demikian berarti walaupun ada upaya untuk mempersempit perlindungan paten oleh Jerman, namun ternyata perlindungan paten dimaksud masih terlalu luas. Perlindungan luas ini, akan menutup kemungkinan dilakukannya modifikasi paten yang bersangkutan oleh pihak lain, karena suatu modifikasi merupakan ekuivalen paten sebelumnya, demikian pula terhadap penemuan yang berbeda dari klaim utama dan tidak terdapat ciri-ciri yang non-esensial.

Apabila Jerman memberikan perlindungan yang luas kepada penemuan, maka Inggris memberikan perlindungan yang sempit bagi suatu penemuan. Sebelum Patents act 1977 berlaku, perundang-undangan paten Inggris tidak mengatur luasnya perlindungan penemuan. Penentuan luasnya perlindungan penemuan dilakukan berdasarkan penafsiran hakim yang dituangkan melalui putusan peradilan. Hal ini sesuai dengan doktrin stare decisis yang dianut sistem hukum Inggris sebagai suatu negara penganut common law system. Adanya kewajiban untuk merumuskan klaim, hakim berpegang kepada pengertian secara gramatikal seperti yang diuraikan di dalam klaim. Pertimbangan-pertimbangan yang diberikan oleh hakim-hakim, dapat dikatakan bahwa tujuan pembatasan monopoli adalah untuk kepastian hukum, dan setiap orang yang melakukan modifikasi terhadap klaim tidak terjatuh ke dalam peniruan yang merupakan perbuatan melanggar hukum.

Setelah berlakunya Patents Act 1977, dalam section 125 ayat (1) diatur luasnya perlindungan penemuan yang sebelumnya tidak dikenal.

${ }^{3}$ Ibid., p. 40. 
Perlindungan dimaksud mengacu kepada Pasal 69 ayat (1) Konvensi Paten Eropa sebagaimana telah dikutip sebelumnya. Akan tetapi di dalam pelaksanaannya hakim tetap memiliki kebebasan yang besar dalam menentukan batas luasnya perlindungan penemuan. ${ }^{4}$ Nampak dalam hal ini, pengadilan Inggris lebih konsisten dengan ciri sistem hukumnya yaitu common law system. Sebagai negara penganut sistem common law, pertimbangan-pertimbangan hukum berkenaan dengan kasus hukum yang ada hingga menjadi preseden yang diikuti oleh pengadilan-pengadilan nampak lebih utama daripada kodifikasi suatu undang-undang, seperti halnya dengan Patents Act 1977.

Pada tahun 1980 terdapat suatu putusan terhadap Catnic v Hill and Smith. Putusan ini boleh dikatakan sebagai suatu Landmark decision. Kasus itu mengenai balok penopang yang dibuat dari plat dan dimasukkan ke tembok-tembok bangunan di atas pintu dan jendela. Klaim utama pemegang paten antara lain berisi ciri-ciri: member yang terdapat pada (a) yaitu yang berada di depan, mempunyai kemiringan 12-13 derajat. Ini berarti bahwa member tersebut tidak dapat dikatakan vertikal, dibanding member (b) yaitu yang di belakang jelas-jelas ventikal. Kemudian ada orang lain yang membuat balok penopang dari baja dengan bagian belakang tidak tepat berdiri vertikal melainkan sedikit miring. Hakim Tinggi Whitford dalam pertimbangannya menyatakan, vertikal bukan merupakan ciri esensial sehingga antara balok yang telah dipatenkan dan balok tergugat tidak terdapat perbedaan. Sedangkan Court of Appeal memandang bahwa vertikal merupakan ciri yang esensial karena apa yang tertulis di dalam klaim, itulah yang dikehendaki oleh pemohon. Oleh karena itulah Court of Appeal memandang bahwa antara balok yang telah dipatenkan dan balok tergugat terdapat perbedaan, sehingga hal ini bukan pelanggaran hukum. Hal ini oleh House of Lords memandang bahwa yang menjadi ukuran adalah purposive construction dari pemohon. Sejak saat itu pengadilan-pengadilan Inggris merujuk ajaran purposive construction. Berpegang pada ajaran ini, lingkup perlindungan paten lebih besar dari sekedar berdasarkan kata-kata klaim. Walaupun demikian tidak seperti di Jerman yang memberi tempat begitu luas pada perlindungan paten. ${ }^{5}$

Dari ketiga negara Eropa yang dibandingkan, nampak walaupun memiliki persamaan yaitu sama-sama menyesuaikan undang-undangnya pada Konvensi Paten Eropa, tetapi dalam memberikan penafsiran terhadap lingkup perlindungan paten atas klaim ternyata memiliki perbedaan yang signifikan. Bagi negara Inggris belum bisa meninggalkan tradisi common law-nya yang lebih mengandalkan precedent. Oleh karena walaupun ada

\footnotetext{
${ }^{4}$ Ibid., p. 40-41.

${ }^{5}$ Ibid., p. 42-43.
} 
undang-undang yang mengatur luas perlindungan yang dimaksud, namun hakim pengadilan mengabaikan, dan lebih merujuk pada precedent. Demikian hal tersebut memberikan dampak terhadap perlindungan paten menjadi lebih sempit bila dibandingkan dengan Jerman, termasuk Belanda.

\section{Perlindungan Paten di Amerika Serikat dan Jepang}

Amerika Serikat memberi pengaturan yang berbeda dengan Konvensi Paten Eropa. Bagian 102 (g) Sertifikat 35 Undang-Undang Amerika Serikat menetapkan bahwa seseorang berhak mendapatkan paten terkecuali jika sebelum penemuan oleh si pemohon tersebut penemuan bersangkutan telah dilakukan di negara ini oleh seseorang lain yang mana orang lain tersebut belum menanggalkan, membekukan, atau membatalkan paten tesebut. Nampak dalam hal ini yang digunakan bukan aturan first-tofile, tetapi first-to-invent yang berlaku. Amerika Serikat dalam hal ini memberikan perlindungan terhadap pengguna paten terdahulu. Dalam hal belum adanya pengguna paten terdahulu, atau pengguna sebelumnya telah membekukan atau membatalkan, barulah si pemohon yang diberikan perlindungan melalui pendaftaran petennya.

Bagian 101 Undang-Undang Paten Amerika mensyaratkan kebaruan (novelty) sebagai suatu syarat bisa dipatenkannya sesuatu, demikian pula bahwa suatu penemuan yang bisa dipatenkan merupakan suatu proses, mesin, perekayasaan, atau komposisi sesuatu yang bermanfaat, atau suatu kemajuan yang bermanfaat darinya. Dalam hubungan ini Bagian 102 Undang-Undang, menetapkan seseorang berhak untuk mendapatkan paten, terkecuali:

a. Penemuan bersangkutan telah dikenal atau digunakan oleh orang lain di negeri ini, atau dipatenkan atau dipaparkan dalam suatu publikasi cetak di negeri ini atau di sebuah negara asing, sebelum penemuan oleh si pemohon paten; atau

b. Penemuan bersangkutan telah dipatenkan atau dipaparkan dalam suatu publikasi cetak di negeri ini atau di sebuah negara asing atau digunakan oleh publik atau dijual di negara ini, lebih dari satu tahun sebelum tanggal permohonan paten di negeri ini; atau

c. Penemuan bersangkutan untuk pertama kalinya dipatenkan atau dibuat untuk dipatenkan, atau menjadi subjek dari sertifikat seorang penemu, oleh si pemohon atau para wakil hukumnya atau orang yang ditunjuknya di sebuah negara asing sebelum tanggal permohonan paten di negara ini atau sertifikat penemu yang diajukan lebih dari 12 bulan sebelum pengajuan permohonan di negeri ini; atau

d. Penemuan dipaparkan dalam sebuah paten yang diberikan atas dasar suatu permohonan untuk paten oleh seseorang lain yang diajukan di negeri ini sebelum penemuan oleh pemohon paten, atau berdasarkan 
suatu permohonan internasional oleh seseorang lain yang telah memenuhi persyaratan untuk memulai level nasional di bawah PCT sebelum penemuannya oleh si pemohon paten.

Syarat lain disebutkan dalam Bagian 103 Undang-Undang, bahwa sebuah paten tidak bisa diperoleh jika perbedaan-perbedaan hukum dalam subject of matter yang diusahakan untuk dipatenkan dan the prior art (penemuan sebelumnya) adalah sedemikian rupa sehingga subject of matter bersangkutan secara keseluruhan, pada saat penemuan dibuat bagi seseorang yang mempunyai keterampilan biasa dalam kecakapan (art) yang dengannya subject of matter bersangkutan berkaitan.

Pada Bagian 102 (e) Undang-Undang menetapkan bahwa seseorang berhak atas suatu paten terkecuali penemuan bersangkutan telah dipaparkan di dalam suatu paten yang diberikan atas suatu permohonan untuk paten oleh seseorang lain yang mana permohonon lain tersebut diajukan di Amerika Serikat sebelum penemuan bersangkutan oleh pemohon paten. Di bawah hukum Amerika Serikat, paten bisa digunakan sebagai prior art (penemuan sebelumnya) baik untuk maksud-maksud baru atau untuk maksud-maksud kejelasan, setelah pemberian paten bersangkutan, dengan efek prior art berlaku surut hingga tanggal pengajuan efektif yang paling awal di Amerika Serikat, dan bukan hingga tanggal pengajuan di luar AS. Ini lazim disebut sebagai "aturan Hilmer".

Nampak dalam hal ini Amerika Serikat tidak seperti negara-negara Eropa. Semakin jelas lagi perbedaan tersebut khususnya bagi Belanda dan Jerman. Dalam menentukan luas perlindungan penemuan paten di dalam praktek menggunakan doktrin file wrapper estoppel dan doktrin equivalent. Ada atau tidaknya pelanggaran terhadap suatu penemuan yang dipatenkan yang pertama kali harus diperhatikan kata-kata klaim, yang berarti penafsiran sempit. Namun pengadilan berpendapat bahwa apabila hanya kata-kata yang harus diperhatikan, hal itu akan menempatkan bentuk lebih tinggi dari pada substansi (arti luas). Sudah barang tentu akan merampas keuntungan yang sedianya diperoleh pemilik penemuan. Hal ini jelas tidak sesuai dengan tujuan utama sistem paten yaitu pengungkapan penemuan yang dilakukan melalui prinsip disclosure. Untuk melindungi pemilik penemuan yang dipatenkan dikembangkan doktrin equivalent.

Menurut doktrin equivalent, apabila dua alat mempunyai fungsi yang sama dengan cara bekerja yang secara substansial sama, dan untuk memperoleh akibat yang secara substansial sama, kedua alat itu dianggap sama, meskipun kedua alat itu berbeda baik nama, bentuk, maupun

\footnotetext{
${ }^{6}$ Japan Patent Office. 2001. "Comparative Study on the Japanese, the United States and the European Patent Systems", makalah dalam rangka Asia-Pacific Industrial Property Center, JIII. yang diselenggarakan Japan Patent Office, p. 8-9.
} 
wujudnya. Secara umum doktrin equivalent memang menguntungkan pemilik penemuan. Namun dari sisi lain doktrin equivalent dapat juga digunakan untuk menyerang pemilik penemuan. Hal ini terjadi apabila alat yang dipatenkan itu diubah sedemikian rupa sehingga cara bekerjanya secara substansial berbeda jauh dari barang yang dipatenkan tetapi berfungsi sama dengan yang telah dipatenkan dan masih tercakup dalam kata-kata klaim. Jika hal itu dilakukan oleh pemilik penemuan lainnya, dan doktrin equivalent yang akan digunakan untuk membatasi klaim itu di dalam sengketa yang terjadi bukan tidak mungkin doktrin itu akan menyulitkan pemegang paten. ${ }^{7}$

Dalam perkembangannya, doktrin equivalent itu berkaitan dengan doktrin file wrapper estoppel. Menurut doktrin file wrapper estoppel, guna memperoleh paten pemilik penemuan membatasi klaimnya. Apabila doktrin file wrapper estoppel telah digunakan dalam mempertahankan patennya dari peniruan, pemegang paten dapat menggunakan doktrin equivalent. Penggunaan doktrin tersebut pada saat ini hanya untuk klaim-klaim yang ambigious dan sebagai alat interpretasi. Dalam kasus Alpex Computer Corporation $v$ Nintendo Company Ltd and Nintendo America, Inc., Mahkamah Agung Amerika Serikat menyatakan Alpex sebagai pemegang paten No. 4,026, 555 menggugat Nintendo bahwa Nintendo telah melakukan pelanggaran terhadap paten tersebut. Dalam kasus ini, Nintendo Amerika salah satu pembuat vidio games terbesar dari Jepang - kehilangan lebih dari US\$ 2.000.000.000.oo (dua milyar dolar) pada awal tahun 90-an. ${ }^{8}$

Baik penggugat (Alpex) maupun tergugat (Nintendo) adalah produsen video games. Posisi kasusnya, berawal dari industri video games telah mulai sejak awal 1970-an. Pada saat ini berkembang dua macam video games dan home video games. Video games dapat dijumpai di tempat-tempat permainan sedangkan home video games biasanya dijumpai di rumah-rumah. Pada tahun 1974, Alpex menemukan suatu sistem yang memungkinkan home video games memainkan berbagai permainan termasuk permainanpermainan dengan gambar yang berotasi. Temuan itu kemudian mendapat paten pada tahun 1977 oleh Alpex. Temuan yang telah dipatenkan itu kemudian dikomersialkan dalam sistem oleh Attari, Mattel, dan Coleco. ${ }^{9}$

Tahun 1980 awal, Nintendo juga masuk ke pasaran home video games dengan Nintendo Entertainment System (NES). Setelah NES menjadi feature pada Consumer Electronic Show 1985, Alpex memberi tahu Nintendo bahwa Nintendo telah melanggar patennya. Oleh karena itulah pada bulan Februari 1986, Alpex menggugat Nintendo, setelah berkali-kali mengusahakan penyelesaian di luar pengadilan. Di pengadilan tingkat pertama Alpex dimenangkan. Pertimbangan pengadilan tersebut adalah antara alat yang

\footnotetext{
${ }^{7}$ Marzuki, Peter Mahmud. Op. Cit., p. 43-45.

${ }^{8}$ Maulana, Insan Budi. Op. Cit., p. 4-5.

${ }^{9}$ Marzuki, Peter Mahmud. Op. Cit., p. 45.
} 
telah dipatenkan dan alat yang dianggap sebagai tiruan dilihat dari segi fungsi, cara dan hasilnya tidak mempunyai perbedaan yang substansial. Namun pengadilan tingkat pertama tersebut tidak membuktikan bahwa kedua alat tersebut benar-benar bekerja dengan cara yang sama secara substansial. Oleh karena itulah kemudian pengadilan tingkat banding menafsirkan doktrin equivalent bukan semata-mata bahwa kedua alat itu equivalence of the functional result, melainkan harus dapat dibuktikan bahwa keduanya mempunyai perbedaan yang tidak substansial dalam cara kerjanya. $^{10}$

Dari sini dapat diketahui bahwa Hukum Amerika Serikat sesungguhnya lebih sempit bila dibandingkan luas perlindungan paten di Inggris. Perlindungan yang sempit memudahkan proses alih teknologi melalui modifikasi paten yang bersangkutan. Insan Budi Maulana mengatakan, para inventor atau para peneliti di negara-negara maju sering mencari "jalan pintas" dengan membaca informasi permintaan paten, kemudian meneliti, mengembangkan, dan melakukan pengembangan atau perbaikan-perbaikan atas kekurangan-kekurangan, kelemahan-kelemahan dari prior art (penemuan sebelumnya). Cara seperti itu jauh lebih cepat, sederhana, tidak membutuhkan biaya yang terlalu besar dan tidak perlu meneliti dari awal. ${ }^{11}$

Bagi negara Jepang, walaupun banyak mengikuti doktrin Amerika Serikat, tetapi dalam menentukan yang berhak atas hak paten menggunakan aturan first-to-file. Dalam Bagian 39 (1) Undang-Undang Paten Jepang, menetapkan bahwa bila dua atau lebih permohonan paten yang berkaitan dengan penemuan yang sama diajukan pada tanggal-tanggal yang berbeda, maka hanya permohonan pertama yang boleh mendapatkan paten untuk penemuan bersangkutan. Ini berarti, Jepang memiliki pengaturan yang sama dengan Undang-Undang Jerman dan juga Konvensi Paten Eropa, sebagaimana telah dikemukakan sebelumnya.

Bagian 29 (1) Undang-Undang Paten Jepang, menentukan penemuan yang tidak menjadi subjek perlindungan paten karena tidak adanya novelty:

(1) Penemuan-penemuan yang dikenal oleh publik di Jepang atau di tempat lain sebelum pengajuan permohonan paten bersangkutan;

(2) Penemuan-penemuan yang secara umum sudah beroperasi di Jepang atau di tempat lain sebelum pengajuan permohonan paten bersangkutan;

\footnotetext{
${ }^{10}$ Marzuki, Peter Mahmud. Op. Cit., p. 46.

${ }^{11}$ Maulana, Insan Budi. Op. Cit., p. 18.
} 
(3) Penemuan-penemuan yang telah dipaparkan di sebuah publikasi yang diedarkan di Jepang atau tempat lain sebelum pengajuan permohonan paten bersangkutan;

Dari syarat-syarat yang dikemukakan di atas ini, dengan sendirinya juga menuntut aplikabilitas industrial. Apabila dibanding dengan ketentuan dalam Bagian 29 (2) Undang-Undang Paten Jepang, bahwa apabila suatu penemuan dengan gampang bisa dibuat, sebelum pengajuan permohonan paten bersangkutan, oleh seseorang yang mempunyai keahlian biasa dalam kecakapan (art) yang dengannya penemuan bersangkutan berkaitan, atas dasar penemuan atau penemuan-penemuan yang diacu pada yang manapun dari alinea-alinea dari sub-alinea (a), suatu paten tidak boleh diberikan untuk penemuan seperti itu.

Bagian 29 bis (1) Undang-Undang menetapkan, bila sebuah penemuan yang diklaim dalam suatu permohonan paten identik dengan sebuah penemuan atau alat (terkecuali penemuan atau alat yang dibuat oleh orang yang sama sebagai penemu dari penemuan yang diklaim dalam permohonan paten) yang diungkapkan dalam spesifikasi atau tulisan-tulisan yang semula dilekatkan pada permintaan akan suatu permohonan lain untuk suatu paten atau suatu permohonan untuk suatu registrasi utility model yang diajukan lebih awal ketimbang permohonan paten dan yang untuknya. Keterbukaan terhadap pemeriksaan publik (Kokai) atau publikasi setelah registrasi paten (Gazette = Lembaran Negara) diberlakukan setelah pengajuan permohonan paten. Paten tidak boleh diserahkan untuk penemuan bersangkutan tanpa peduli akan Bagian 29 (1). Meskipun demikian, ketetapan ini tidak akan berlaku bila, pada saat pengajuan permohonan paten, si pemohon paten dan pemohon untuk permohonan lain untuk paten atau permohonan untuk suatu registrasi utility model adalah orang yang sama.

Jepang dalam memberikan luas perlindungan penemuan paten di dalam praktek banyak mengikuti doktrin-doktrin file wrapper estoppel dan equivalent yang berlaku di Amerika serikat, di samping Undang-Undang Paten Jepang yaitu Undang-Undang Nomor 21/1959 yang juga mengatur luas perlindungan penemuan. Dalam kasus Badische Anilin and Soda Fabrik A.G. v Sekiskui Kagaku Kogyo KK and Sekisui Sponge, District Court Osaka menafsirkan luasnya perlindungan penemuan dengan menerapkan doktrin equivalent. Pengertian equivalent yang dikembangkan oleh pengadilan Jepang itu sama dengan yang dianut di Amerika Serikat dibanding doktrin file wrapper estoppel, diterapkan dalam kasus Muranaka $v$ K. K. Daiwa Gomu Seisakusho. Oleh karena sistem hukum Jepang didasarkan atas tradisi Civil Law, prinsip iktikad baik yang terdapat dalam Kitab Undang-Undang Hukum Perdata Jepang digunakan dalam situasi pada saat doktrin file wrapper estoppel diterapkan. Dari sistem tersebut, yang dapat dikatakan seimbang dalam memberikan perlindungan antara pemegang 
paten dan masyarakat adalah sistem Amerika Serikat dan tentu saja Jepang yang memang meniru sistem Amerika. Di dalam sistem Amerika Serikat tersebut, terbuka kesempatan bagi hakim untuk melakukan penafsiran secara teologis, yaitu sesuai dengan kepentingan yang dihadapi pada saat itu. Hal ini dimungkinkan karena luasnya perlindungan penemuan tidak diatur di dalam perundang-undangan. Oleh karena itu di dalam menentukan luasnya perlindungan penemuan tersebut diserahkan kepada kebijaksanaan hakim. Hal itu sesuai dengan sistem Common Law yang dianut oleh Amerika Serikat. Di dalam sistem Common Law hakim memang memiliki diskresi yang besar. ${ }^{12}$

Dalam hubungannya dengan sistem hukum common law, Friedman menyatakan common law berbeda dalam banyak hal dengan tatanan hukum di negara-negara Eropa lainnya, seperti Perancis, Belanda, termasuk Indonesia yang menganut sistem hukum civil law. Satu hal yang penting bahwa common law menolak kodifikasi. Tidak pernah ada semacam Kitab Undang-Undang Napoleon di Inggris. Prinsip dasar hukumnya tidak ditemukan dalam undang-undang yang dibuat Parlemen, dan hanya sebagian kecil ditemukan melalui pernyataan hukum yang sistematis, rinci yang disahkan oleh badan-badan legislatif atau diberlakukan melalui ketetapan. Prinsipnya terdapat pada hukum perkara (case law - dalam perangkat pendapat yang ditulis oleh hakim, dan dikembangkan oleh hakim dalam memutuskan perkara tertentu. Doktrin "precedent"- maksim yang berbunyi bahwa hakim terikat oleh apa yang telah diputuskan - adalah doktrin common law yang kuat ${ }^{13}$ Contoh konkrit doktrin common law yang dimaksud, menyangkut luas perlindungan penemuan paten adalah doktrin "purposive construction" yang diikuti oleh pengadilan-pengadilan Inggris, doktrin file wrapper estoppel dan equivalent yang berlaku di Amerika serikat yang tidak saja diikuti pengadilan Amerika Serikat tetapi Jepang ikut mengadopsi doktrin ini.

Menurut Peter, Jepang yang menganut tradisi Civil Law ternyata tidak segan-segan "mengimpor" doktrin-doktrin yang berkembang di dalam sistem Common Law. Doktrin-doktrin sistem Common Law itu berhasil dikemas di dalam prinsip yang lazim digunakan di dalam sistem Civil Law. Keterampilan semacam itu sangat dibutuhkan dalam mengembangkan hukum yang sesuai dengan kebutuhan masyarakat yang oleh Selznick dan Nonnet disebut sebagai Responsive Law. ${ }^{14}$

\footnotetext{
${ }^{12}$ Marzuki, Peter Mahmud. Op. Cit., p. 47.

13 Friedman, Lawrence M. (2001). American Law an Introduduction, Second Edition. Terjemahan Basuki, Wishnu. Hukum Amerika-Sebuah Pengantar. Jakarta: PT. Tatanusa, p. 21-22.

${ }^{14}$ Peter Mahmud Marzuki, Op. Cit., p. 48.
} 
Apa yang terjadi dengan negara Jepang kita harus akui, namun terjadinya percampuran sistem hukum civil law dan common law seperti itu dapat terjadi pada semua negara. Sistem hukum yang di dalamnya meliputi struktur, substansi, dan budaya hukum, selalu dapat berubah mengikuti perkembangan yang terjadi dari waktu ke waktu, bahwa sistem hukum tidak pernah statis. Sistem hukum berubah bersama waktu yang berganti. ${ }^{15}$ Hardijan Rusli menyatakan, setelah berabad-abad terjadi hubungan antara kelompok civil law dengan common law, maka kedua kelompok ini masingmasing lebih mendekatkan diri satu sama lainnya, terutama tahun-tahun belakangan ini yang merupakan era globalisasi. ${ }^{16}$ Contohnya, keputusan hakim yang dulunya di negara civil law bukan merupakan sumber hukum, tetapi sekarang sudah pula dianggap sebagai sumber hukum sama seperti perundang-undangan. Begitu pula negara common law, sekarang sudah mempunyai banyak sekali peraturan tertulis (perundang-undangan) dan kedudukannya juga seperti di negara civil law.

\section{Perlindungan Paten di Indonesia}

Di Indonesia dari waktu ke waktu dilakukan penyempurnaan terhadap peraturan tentang hak paten. Sebelum berlaku Undang-Undang No. 14 Tahun 2001 tentang Paten, kita sudah mengenal Undang-Undang No. 13 Tahun 1997 bahkan sebelumnya Undang-Undang No. 6 Tahun 1989. Penyempurnaan terhadap berbagai ketentuan tersebut, selain bermaksud untuk mengatasi hambatan yang dirasakan dalam praktek kurang memberi perlindungan hukum bagi seorang penemu, juga dimaksudkan dalam rangka penyesuaian dengan perjanjian-perjanjian internasional seperti Persetujuan TRIPs yang telah ditandatangani Indonesia. Harapan besar dalam perubahan dan penyesuaian ini adalah untuk menghapuskan berbagai hambatan, terutama juga untuk memberikan fasilitas yang mendukung upaya meningkatkan pertumbuhan ekonomi perdagangan baik secara nasional maupun internasional. ${ }^{17}$

Dalam Pasal 2 Undang-Undang No. 14 Tahun 2001, ditentukan:

(1) Paten diberikan untuk Invensi yang baru dan mengandung langkah inventif serta dapat diterapkan dalam industri.

(2) Suatu Invensi mengandung langkah inventif jika Invensi tersebut bagi seseorang yang mempunyai keahlian tertentu di

\footnotetext{
${ }^{15}$ Lawrence M. Friedman, Op. Cit., p. 25.

${ }^{16}$ Rusli, Hardijan. (1996). Hukum Perjanjian Indonesia dan Common Law. Jakarta: Pustaka Sinar Harapan, p. 18.

17 Gautama, Sudargo. dkk. (1998). Pembaharuan Undang-Undang Paten 1997. Bandung: Citra Aditya Bakti, p. 7.
} 
bidang teknik merupakan hal yang tidak dapat diduga sebelumnya.

(3) Penilaian bahwa suatu Invensi merupakan hal yang tidak dapat diduga sebelumnya harus dilakukan dengan memperhatikan keahlian yang ada pada saat permohonan diajukan atau yang telah ada pada saat diajukan permohonan pertama dalam hal permohonan itu diajukan dengan Hak Prioritas.

Substansi peraturan tersebut sama dengan peraturan yang berlaku sebelumnya melalui Undang-Undang No. 13 Tahun 1997. Hal yang membedakan bahwa Undang-Undang No. 14 Tahun 2001 mengatur lebih tegas dan jelas. Dalam undang-undang ini, suatu Invensi dianggap baru jika pada tanggal penerimaan, Invensi tersebut tidak sama dengan teknologi yang diungkapkan sebelumnya, dengan syarat bahwa teknologi yang dimaksud telah diumumkan di Indonesia atau di luar Indonesia dalam suatu tulisan, uraian lisan atau melalui peragaan, atau dengan cara lain yang memungkinkan seorang ahli untuk melaksanakan Invensi tersebut sebelum tanggal penerimaan atau tanggal prioritas. Ditegaskan pula, teknologi dimaksud mencakup dokumen permohonan yang diajukan di Indonesia yang dipublikasikan pada atau setelah tanggal penerimaan yang pemeriksaan substantifnya sedang dilakukan, tetapi tanggal penerimaannya lebih awal daripada tanggal penerimaan atau tanggal prioritas permohonan.

Satu hal yang perlu disampaikan berlaku dalam sistem hukum paten bahwa sekalipun penemuan (Invensi) memenuhi kriteria baru tidak selalu berhak atas paten karena penemuan itu tidak dapat dipatenkan. Insan Budi Maulana menyatakan, suatu penemuan baru yang tidak dapat dipatenkan: ${ }^{18}$

a. Apabila bertentangan dengan moral termasuk moralitas agama, ketertiban umum, atau kesusilaan. Hal ini dicontohkan pada pengkloningan domba bisa ditolak penemuan patennya apabila penemuan itu bertentangan dengan agama. Hal yang sama dengan penemuan teknologi nuklir yang berkaitan dengan militer tidak dapat dipatenkan sebagaimana terjadi di jepang, tetapi jika berkaitan dengan pertanian dapat dipatenkan;

b. Apabila penemuan itu merupakan metode pemeriksaan, perawatan, pengobatan, dan pembedahan yang diterapkan terhadap manusia dan hewan, tetapi tidak menjangkau produk apapun yang digunakan, atau berkaitan dengan metode tersebut, seperti metode "terkun" untuk pengobatan;

c. Apabila penemuan itu merupakan teori dan metode di bidang ilmu pengetahuan dan matematika, seperti program komputer. Di negara lain, seperti amerika serikat atau jepang, program komputer dapat dipatenkan.

${ }^{18}$ Maulana, Insan Budi. Op. Cit., p. 14-15. 
Nampak dari beberapa ketentuan berkenaan dengan syarat suatu penemuan paten diberikan, memiliki persamaan dengan pengaturan yang berlaku di negara-negara Eropa dan Jepang. Dibanding dengan Amerika Serikat hal tersebut berbeda, dalam menentukan pihak yang paling berhak untuk mendapatkan perlindungan paten jika ada 2 (dua) pihak yang mengajukan permintaan.

Pengaturan Undang-Undang Paten Indonesia dalam menentukan luas perlindungan paten bila terjadi sengketa, belum bisa dinyatakan memiliki aturan yang jelas, apabila hanya mensyaratkan klaim yang harus dimuat di dalam permintaan paten yang diajukan dengan tanpa diberi penjelasan sedikit pun tentang klaim yang dimaksud, berdasarkan kata-kata dari klaim atau intisari dari klaim.

Suatu perlindungan berdasarkan intisari klaim membawa konsekuensi perlindungan itu terlalu luas sehingga tertutup kemungkinan dilakukannya modifikasi meskipun bentuk dan wujudnya berbeda, karena dalam intisari klaim yang dipentingkan adalah fungsi penemuan yang sama. Sebaliknya, apabila kata-kata dari klaim yang dilindungi memudahkan modifikasi tetapi mudah dilakukan peniruan. Seorang peniru hanya dengan mempelajari deskripsi yang mengungkapkan penemuan yang dipatenkan, dapat mengubah kata-kata dari klaim dan sekaligus mengadakan perubahan kecil yang tidak signifikan, tidak dianggap sebagai pelanggaran paten. Penafsiran demikian jelas tidak akan mempunyai arti bagi perlindungan pemegang paten yang dapat menimbulkan rasa enggan kepada penemu untuk meminta perlindungan melalui pendaftaran temuannya. Berdasarkan alasan ini, Peter mengajukan saran agar penafsiran terhadap klaim yang dimuat di dalam permintaan paten menggunakan penafsiran secara teleologis yaitu penafsiran didasarkan atas kepentingan yang dihadapi saat itu. Berdasarkan hal ini maka yang dilindungi bukan hanya kata-kata klaim tetapi juga bukan intisari klaim. Akan tetapi kata-kata dari klaim dijadikan landasan atau dasar, sedangkan deskripsi, gambar, dan abstraksi merupakan penjelasan dari klaim. Keuntungan dari penafsiran ini adalah peminta paten hendaknya merumuskan secara cermat dan tegas klaim yang dimintakan perlindungan. Di samping itu gambar, deskripsi, maupun abstraksi hendaklah mendukung kata-kata klaim tersebut. Begitu pula mengenai bentuk dan wujud juga menentukan perlindungan. Sedangkan fungsi bukan merupakan objek perlindungan sebab jika fungsi yang dilindungi akan menutup kemungkinan pihak lain untuk mendapatkan perlindungan paten bagi penemuan dengan fungsi yang sama. ${ }^{19}$

Penafsiran teleologis yang disarankan memberi makna pada persetujuan terhadap apa yang dilakukan oleh Jepang yang mengikuti

${ }^{19}$ Peter Mahmud Marzuki, Op. Cit., p. 49-50. 
Amerika serikat dalam penggunaan doktrin file wrapper estoppel dan equivalent. Bagi saya, meniru yang baik bukanlah suatu kejahatan. Bahkan dalam bidang hukum paten yang bersifat universal jusru lebih baik karena memang inilah yang menjadi salah satu tujuan Persetujuan TRIPs. Apa yang dipraktekan oleh Jepang yang mengadopsi doktrin file wrapper estoppel dan equivalent lebih memberikan perlindungan yang seimbang antara kebutuhan alih teknologi dan kepentingan perlindungan pemegang paten. Kedua doktrin secara bergandengan di dalam pemanfaatannya sudah teruji bagi perkembangan teknologi di Jepang dan Amerika Serikat. Indonesia sebagai penganut sistem hukum civil law bukan harga mati dalam mengadopsi sistem hukum common law. Lebih dari itu, jika dihubungkan dengan Hukum Adat Indonesia sesungguhnya lebih mendekati ke sistim hukum cammon law. Sekarang ini Indonesia dikenal sebagai penganut civil law, sesungguhnya hanya karena kecelakaan sejarah, yang kebetulan pernah dijajah oleh Belanda.

\section{Penutup}

\section{Simpulan}

Perlindungan paten baik bagi negara-negara Eropa yang mengikuti Konvensi Paten Eropa, Jepang maupun Indonesia memiliki persamaan dalam memberikan perlindungan paten berdasarkan prinsip first-to-file, yang berbeda dengan Amerika Serikat berdasarkan prinsip first-to-invent. Sekalipun Amerika Serikat menggunakan prinsip first-to-invent, tetapi Amerika Serikat juga mengatur syarat perlindungan sebagaimana negaranegara Eropa, Jepang dan Indonesia yang berupa penemuan baru, mengandung langkah inventif, dan dapat diterapkan dalam industri.

Perbedaan di antara negara-negara Eropa bahwa Jerman merupakan negara yang memberikan perlindungan paten paling luas, sementara Inggris merupakan negara yang memberikan perlindungan paten lebih sempit dibanding Belanda, tetapi lebih luas dibanding Amerika Serikat dan Jepang yang keduanya sama menggunakan doktrin "file wrapper estoppel dan equivalent". Adapun Indonesia hanya menyebutkan secara umum tanpa merinci lingkup perlindungan - dari segi kata-kata dalam klaim atau intisari (substansi) klaim yang menjadi pegangan hakim.

Sistem hukum common law banyak mempengaruhi perlindungan hak paten secara sempit. Inggris dan Amerika Serikat sebagai negara yang sama menganut common law system, namun dalam hal menentukan lingkup perlindungan hak paten keduanya merujuk pada doktrin hukum yang berbeda dimana Inggris merujuk pada doktrin "purposive construction" dan Amerika Serikat merujuk pada doktrin "file wrapper estoppel dan equivalent" yang diikuti oleh hakim-hakim pengadilan Jepang. Dalam 
hubungan ini pengaruh civil law system hanya sebatas dalam bentuk pengaturan luas perlindungan hak paten melalui undang-undang yang tidak mengikat pengadilan setiap negara, kecuali Jerman yang secara kaku berpegang pada kodifikasinya.

\section{Saran}

Indonesia yang sekarang ini dalam undang-undangnya masih mengatur secara umum lingkup perlindungan hak paten, disarankan mengikuti prilaku hakim pengadilan Jepang yang mengadopsi doktrin file wrapper estoppel dan equivalent sebagaimana berlaku di Amerika Serikat. Hal ini didasarkan pertimbangan bahwa doktrin yang dimaksud memberikan keseimbangan pada perlindungan pemegang paten, di samping perlindungan kepentingan negara dalam proses alih teknologi.

\section{Daftar Pustaka}

Friedman, Lawrence M. (2001). American Law an Introduduction, Second Edition. Terjemahan Basuki, Wishnu. Hukum Amerika-Sebuah Pengantar. Jakarta: PT. Tatanusa.

Gautama, Sudargo. dkk. (1998). Pembaharuan Undang-Undang Paten 1997. Bandung: Citra Aditya Bakti.

Japan Patent Office. tanpa tahun. "Comparative Study on the Japanese, the United States and the European Patent Systems", makalah dalam rangka Asia-Pacific Industrial Property Center, JIII. yang diselenggarakan Japan Patent Office.

Marzuki, Peter Mahmud. (2000). Luasnya Perlindungan Paten, dalam Kapita Selekta Hak Kekayaan Intelektual I. Pusat Studi Hukum UII Yogyakarta Bekerja Sama dengan Yayasan Klinik HAKI Jakarta.

Maulana, Insan Budi. (2000). Penerapan Paten Sejak UU Paten No. 6 Tahun 1989 Hingga UU Paten No. 13 Tahun 1997: Pengalaman Indonesia Selama Ini, dalam Kapita Selekta Hak Kekayaan Intelektual I. Pusat Studi Hukum UII Yogyakarta Bekerja Sama dengan Yayasan Klinik HAKI Jakarta.

Rusli, Hardijan. (1996). Hukum Perjanjian Indonesia dan Common Law. Jakarta: Pustaka Sinar Harapan. 